\title{
Contribution of leading commodities to the economy of Sarolangun Regency, Jambi Province
}

\author{
Suandi $^{1 *}$; Dedy Hendry²; Ajra $^{2}$; Syahrasaddin ${ }^{3}$ \\ 1) Department of Agribusiness, Faculty of Agriculture, Universitas Jambi, Indonesia \\ ${ }^{2)}$ Government of Sarolangun Regency, Jambi Province, Indonesia \\ 3) CV Dinamika Tehnik Jambi consultant, Indonesia
}

*To whom correspondence should be addressed.Email:suandi_pertanian@unja.ac.id

\begin{abstract}
This study aims to analyze the contribution of leading commodities to the economy of Sarolangun Regency, Jambi Province. The data used are time series data from 2013-2017, the 2013-2017 GRDP of Sarolangun Regency, the 2013-2017 GRDP of Jambi Province and the 2013-2017 Sarolangun Regency population data. Data were descriptively analyzed using the Klassen typology approach. There were six prime sectors based on the calculation results through Klassen typology during 2013-2017, namely: (1) mining and excavating; (2) water supply, waste management, waste, and recycling; (3) financial services and insurance; (4) administration of government, defense, and mandatory social security; (5) health services and social activities; and (6) other services, while other sectors were classified as potential sectors, developed sectors, and underdeveloped sectors.
\end{abstract}

Keywords: GRDP, Klassen typology, Leading commodity, Prime sector

JEL Classifications: $\mathrm{O} 11, \mathrm{O} 47$

\section{INTRODUCTION}

Data showed a fairly high increase in Sarolangun Regency's economic growth rate each year. It was only 3.59 percent in 2015, then it rose to 4.26 percent in 2016 and it increased again to 4.69 percent in 2017 (BPS, 2018). This increase was also accompanied by a high population growth rate of 2.27 percent during 2010-2017, much higher than Jambi Province's rate of only 1.89 percent per year. Theoretically, any increase in the population economy will reduce the number of population adversely affecting regional development and poverty (Suandi, Yuslidar, Suma \& Damayanti, 2014). It also has negative impact on household food security and consumption (Suandi, Napitupulu \& Damayanti, 2018).

The latest data showed that Sarolangun Regency's poverty rate in 2015 was 28,500 people, or 10.29 percent of the total population (of 278,222 people). This fell to 26,370 people in 2016, or 9.33 percent of the total population (284,201 people). In other words, there has been a 7.48 percent fall. The poverty rate also recorded a drop of 8.87 percent in 2017. Although it has dropped significantly each year, there were about 25,744 people (8.87 percent) in economically weak (poor) groups. These figures are still higher than the poverty rate of Jambi Province (8.19 percent). Future development plans with due regard to poverty rates must be carried out in a comprehensive and holistic manner, oriented to the concept of sustainable development of welfare (Howarth, 2012). 
Local governments have broader authority with the policy of regional autonomy and fiscal decentralization, both in drawing up development plans and in financing and implementing them according to the potential of each region. As an integral part of the national development process, plans and implementation of regional development activities are carried out in an integrated manner with the achievement of national development goals (Republik Indonesia, 2014).

Studies on basis sectors (leading sectors) are quite important because they are very useful to inform the success and development policies, especially economic development. The success of regional development seems to give its own contribution to the region, depends on the development goals and the potential of the region. Theoretically, the rate of economic growth of a region depends on economic activities, especially basis sectors (Tarigan, 2012). Based on this, the objectives of this study are to find out and analyze the contribution of leading commodities to the economy of Sarolangun Regency, Jambi Province.

\section{LITERATURE REVIEW}

Regional economic development is a process whereby local government and community manage existing resources and form a partnership pattern between local government and private sector to create job opportunities and stimulate the development of economic activities/economic growth in the area (Arsyad, 2010).

Economic growth is the process of changing a country's economic conditions on an ongoing basis towards a better condition for a certain period. Economic growth is an indication of the success of national development (Sukirno, 2011). According to Tarigan (2012), economic growth is the increase in income of society as a whole, namely the increase of added value. Added income is revenue calculated from the value of goods and services produced in a country or region in a given year, called Gross Regional Domestic Product (GRDP) (Sukirno, 2011). According to Neoclassical theory, economic growth rate results from a combination of three economic resources, namely the accumulation of capital, increasing job offers, and technology. Improvement of technology is seen from skill improvement or technological advances so that productivity per capita increases (Tarigan, 2012).

Economic growth of each country or region needs to see which sectors or commodities that have great potential and can be developed quickly, either because of natural potential or their competitive advantage to be developed or known as Turnpike Theory (Tarigan, 2012). According to Sjafrizal (2008), high economic growth rate is still the main target in preparing national and regional development plans in addition to the physical and social development, while the growth rate varies greatly adjusted to the economic potential of each region.

In order to increase economic growth rate, it's very important to distinguish between basis sectors and non-basis sectors. Basis sector in a growth center is the sector whose growth can determine the development in the whole area. Non-basis sector is a secondary sector in the sense that the sector grows as a result of comprehensive development in the area.

Economic base theory seeks to determine basis sectors of an area then from the determination of the sectors, sector activities can be predicted. The information can be used to analyze additional impacts of related sector activities (Sugiyanto \& Sukesi, 2010). Analysis of basis sectors of a region can be done with four approaches, namely the direct method, the indirect method, the mixed method, and Location Quotient (LQ) method. 
One of the commonly used methods is Location Quotient (Tarigan, 2012). LQ method compares the industry's share or regional employment and/or GRDP of the research area with its share of national employment and/or GRDP at the Provincial/National level.

According to Sugiyanto \& Sukesi (2010), creation of centers of economic growth can be started from some dynamic sectors and sectors that have high output ratios, and in certain regions, it can be sectors that can have spread effect and multiple effect on other sectors and broader area. The implementation of the creation a growth center must be followed by trickledown effect and spread effect through a harmonious activity between the growth center and resources in the rural area, so that growth center activities have an impact on the surrounding area.

Based on the analysis results, it was found that leading sectors in the growth center area in East Java were Agriculture sector, followed by Electricity, Gas, and Water sector, Construction, Services sector, Financial sector, Rental and Company Services sector, Transportation and Communication sectors, Trade, Hotel and Restaurant sector, Manufacturing sector, and mining and excavating sector (Arifin, 2008). The study of Suandi, Delis \& Rainiyati (2015) added that sector and subsector that contributes the most to the GRDP of the regency was Agriculture sector, reaching 40.4 percent. Subsector that has the potential to increase economic growth rate is food crops subsector (Srikandi, Palar \& Wauran, 2015). Qomariah, Mustapit \& Supriono (2018) found that food crops commodity in Bondowoso Regency was a basis commodity.

Recent research findings indicate that the Agriculture sector, especially plantation, is still the main livelihood of farmers. Same as the findings of Suandi \& Napitupulu (2016), it was found that plantation sector, especially coffee plantation in Kerinci Regency, was a basis sector. It showed that coffee plantations played a major role in the economy of Kerinci Regency. Also coffee plantations in Kerinci Regency had a role in regional development, because they had the potential to give high income and high labor absorption. The same result was shown by Tirani, Pranoto \& Moelyo (2018). Agriculture sector was able to make a significant contribution to the regional economy, especially the plantation subsector.

Studies on the contribution of basis sectors and non-basis sectors' activities can also be carried out through the development of each economic sector. By grouping them with Klassen typology, the distribution of subsectors in each region, both primary, secondary, and tertiary subsector, are: prime subsector, potential subsector, developed sector, and underdeveloped sector (Arianti, 2011).

According to Sjafrizal (Hajeri, Yurisinthae \& Dolorosa, 2015), Klassen typology is used to find the pattern and structure of economic growth in each region. Classification of the regional economy can be seen through Klassen typology analysis. Based on the Klassen concept, Klassen typology analysis divides regions based on two indicators, namely economic growth and contribution of each subsector to regional GRDP. The results of the study by Arianti (2011) found that in the economic development in Bengkulu Province during 2003-2009, livestock subsector was the prime sector, plantation subsector was the potential sector, forestry was the developed subsector, and food crops subsector was underdeveloped.

\section{METHODS}

The research variables are: (a) Gross Regional Domestic Product (GRDP) of Sarolangun Regency and of Jambi Province, (b) revenue of leading commodities of 
Sarolangun Regency and of Jambi Province, (c) the number of labors in leading commodities of Sarolangun Regency and of Jambi Province.

The data used in this study are secondary data, namely time series data from 20132017. Data were obtained from relevant agencies, such as Badan Perencanaan dan Pembangunan Daerah (Bappeda/Regional Development Planning Agency) of Sarolangun Regency, Bappeda of Jambi Province, Reports of BPS Sarolangun Regency, and Reports of BPS Jambi Province. Other data sources were obtained from research reports, journals, and magazines which discuss the role of leading commodities in the regional economy. To get the research purposes of the contribution of the leading commodities to the economy of Sarolangun Regency (revenue and business fields), the analysis is carried out through the approach of Klassen typology. Through Klassen typology analysis, this study can classify research areas in Sarolangun Regency. Based on the Klassen concept, the analysis divides regions based on two indicators, namely economic growth and the contribution of each subsector to regional GRDP (Table 1).

Table 1. Classifications of comparative advantages of commodities based on Klassen typology

\begin{tabular}{c|cc}
\hline Crowth rate & Kij $\geq$ Kin & Kij $<$ Kin \\
\hline Rij $\geq$ Rin & Prime Subsector & Developed Subsector \\
\hline Rij $<$ Rin & Potential Subsector & Underdeveloped Subsector \\
\hline
\end{tabular}

Source: Arianti, 2011.

Notes: $R_{i j} \quad$ : Growth rate of $i$-th subsector in area $j$ (regency)

Rin : Growth rate of $i$-th subsector in area $n$ (province)

$K_{i j} \quad:$ Contribution of $i$-th subsector in area $j$ (regency)

Kin : Contribution of $i$-th subsector in area $n$ (province)

\section{RESULTS AND DISCUSSION}

\section{Classification of comparative advantages}

Through the analysis of Klassen typology, this study can classify research areas in Sarolangun Regency. Based on the Klassen concept, the analysis divides regions based on two indicators, namely economic growth and contribution of each subsector to regional GRDP. From the determination of the average growth rate and the average contribution rate of subsectors to the regional GRDP, commodities (subsectors) are divided into four groups, namely: (1) prime commodity (subsector), (2) potential subsector, (3) developed subsector, and (4) underdeveloped subsector.

Based on the classification by Klassen typology, the distribution of subsectors in each area in Sarolangun Regency is obtained, including primary, secondary, and tertiary subsector. The results of the analysis showed that the sector and subsector which had the biggest contribution to the GRDP of Sarolangun Regency were Agriculture sector, reaching 28 percent. The figure was far lower than the contribution of Agriculture, Forestry, and Fisheries sector in Merangin Regency (40.4 percent), however it was slightly higher than the contribution of Agriculture, Forestry, and Fisheries sector in Jambi Province (26.97 percent) (Table 2). Growth rate of Agriculture sector in Sarolangun Regency was slightly lower than the growth rate of Agriculture sector in Jambi Province (Table 3). 
The results through Klassen typology showed that based on its comparative advantage (Table 3), in Sarolangun Regency in 2013, prime subsectors were mining and excavating sector; Administration of Government, Defense, and Mandatory Social Security sector; and Health Services and Social Activities sector. These prime sectors were those that were able to compete with the sectors at the level of Jambi Province, both in terms of growth rate and contribution to the regional economy.

Table 2. Contribution and growth rate of subsectors to the GRDP of Sarolangun Regency and Jambi Province at constant-price based on business fields, 2017

\begin{tabular}{lcccc}
\hline \multirow{2}{*}{\begin{tabular}{l} 
Business Fields \\
\cline { 2 - 5 }
\end{tabular}} & $\begin{array}{c}\text { Jambi } \\
\text { Province }\end{array}$ & $\begin{array}{c}\text { Sarolangun } \\
\text { Regency }\end{array}$ & $\begin{array}{c}\text { Jambi } \\
\text { Province }\end{array}$ & $\begin{array}{c}\text { Sarolangun } \\
\text { Regency }\end{array}$ \\
\hline A. Agriculture, forestry, and fisheries & 5.43 & 4.20 & 26.97 & 28.95 \\
B. Mining and excavating & 3.77 & 5.12 & 23.57 & 21.20 \\
C. Manufacturing & 3.02 & 3.52 & 10.76 & 4.01 \\
D. Procurement of electricity and gas & 1.70 & 6.51 & 0.05 & 0.03 \\
E. Water Supply, waste management, & 2.60 & 3.34 & 0.13 & 0.13 \\
$\quad$ waste, and recycling & 7.22 & 5.00 & 7.19 & 14.34 \\
F. Construction & 4.33 & 4.63 & 9.61 & 8.17 \\
G. Large and retail trade; car and & 5.91 & 5.55 & 3.28 & 2.01 \\
$\quad$ motorcycle repair & 7.95 & 7.82 & 1.11 & 2.14 \\
H. Transportation and warehousing & 6.60 & 5.30 & 3.61 & 3.69 \\
I. Provision of accommodation and foods & 3.06 & 4.05 & 2.35 & 2.69 \\
$\quad$ and beverages & 4.61 & 3.93 & 1.44 & 1.32 \\
J. Information and communication & 4.32 & 5.45 & 1.05 & 0.27 \\
K. Financial services and insurance & 2.52 & 3.05 & 3.42 & 5.64 \\
L. Real estate & 4.24 & 3.93 & 3.26 & 2.71 \\
M.N. Company services & 5.49 & 6.60 & 1.15 & 1.30 \\
O. Administration of government, defense & & & \\
$\quad$ and mandatory social security & 4.54 & 5.70 & 1.03 & 1.40 \\
P. Educational services & Q. Health services and social activities &
\end{tabular}

Source: BPS Jambi Province and Sarolangun Regency (2018) (processed).

Table 3 shows that agriculture, forestry, and fisheries sector is classified as potential sector, even though agriculture sector is the mainstay in the economy of Sarolangun Regency, both as foreign exchange earner and jobs provider. Agriculture forestry, and fisheries sector had the biggest contribution to the economy of Sarolangun Regency, reaching 27.04 percent and the percentage was even higher than that of Jambi Province (25.12 percent). Future development in investment needs to be a serious concern for Sarolangun Regency government because this sector is the mainstay of the regional economy.

The results of the study contradicted the findings of Wibowo, Darsono \& Nurjayanti (2016) that basis sectors in Temanggung Regency during 2009-2013 were agriculture sector, electricity and clean water sector, transportation and communication sector, financial sector, rental and company services sector, and Services sector. Agriculture subsectors which became basis subsectors in Temanggung Regency during 2009-2013 were plantation subsector and livestock and livestock products subsector. Results of another study showed that the leading subsectors were livestock subsector and plantation subsector (Pratama, Sukiyono \& Arianti, 2017). 
Table 3. Growth rate and distribution of GRDP of Jambi Province and Sarolangun Regency, 2013

\begin{tabular}{|c|c|c|c|c|c|}
\hline \multirow[b]{2}{*}{ Business Fields } & \multicolumn{2}{|c|}{ Growth rate } & \multicolumn{2}{|c|}{ Contribution } & \multirow{2}{*}{$\begin{array}{l}\text { Comparative } \\
\text { Advantage }\end{array}$} \\
\hline & $\begin{array}{c}\text { Jambi } \\
\text { Province }\end{array}$ & $\begin{array}{c}\text { Sarolangun } \\
\text { Regency }\end{array}$ & $\begin{array}{c}\text { Jambi } \\
\text { Province }\end{array}$ & $\begin{array}{c}\text { Sarolangun } \\
\text { Regency }\end{array}$ & \\
\hline $\begin{array}{l}\text { A. Agriculture, forestry, and } \\
\text { fisheries }\end{array}$ & 6.21 & 5.66 & 25.12 & 27.04 & Potential \\
\hline B. Mining and excavating & 3.83 & 6.85 & 26.57 & 29.45 & Prime \\
\hline C. Manufacturing & 8.17 & 7.43 & 11.64 & 4.29 & Underdeveloped \\
\hline $\begin{array}{l}\text { D. Procurement of electricity and } \\
\text { gas }\end{array}$ & 8.73 & 13.32 & 0.05 & 0.02 & Developed \\
\hline $\begin{array}{l}\text { E. Water Supply, waste mana- } \\
\text { gement, waste, and recycling }\end{array}$ & 1.87 & 1.78 & 0.14 & 0.13 & Underdeveloped \\
\hline F. Construction & 19.49 & 17.90 & 7.03 & 11.86 & Potential \\
\hline $\begin{array}{l}\text { G. Large and retail trade; car and } \\
\text { motorcycle repair }\end{array}$ & 8.22 & 8.07 & 8.77 & 6.79 & Underdeveloped \\
\hline H. Transportation and warehousing & 7.88 & 8.50 & 3.03 & 1.77 & Developed \\
\hline $\begin{array}{l}\text { I. Provision of accommodation and } \\
\text { foods and beverages }\end{array}$ & 6.40 & 4.67 & 0.92 & 1.79 & Potential \\
\hline J. Information and communication & 6.53 & 4.09 & 3.24 & 3.04 & Underdeveloped \\
\hline K. Financial services and insurance & 11.81 & 9.16 & 2.38 & 2.64 & Potential \\
\hline L. Real estate & 4.93 & 3.56 & 1.52 & 1.29 & Underdeveloped \\
\hline M.N. Company services & 2.04 & 3.54 & 1.05 & 0.24 & Developed \\
\hline $\begin{array}{l}\text { O. Administration of government, } \\
\text { defense and mandatory social } \\
\text { security }\end{array}$ & 4.57 & 5.09 & 3.27 & 4.30 & Prime \\
\hline P. Educational services & 5.39 & 6.38 & 3.31 & 2.89 & Developed \\
\hline $\begin{array}{l}\text { Q. Health services and social } \\
\text { activities } \\
\text { R.S.T.U. Other services }\end{array}$ & $\begin{array}{l}8.07 \\
4.80\end{array}$ & $\begin{array}{l}9.16 \\
3.68\end{array}$ & $\begin{array}{l}0.99 \\
0.99\end{array}$ & $\begin{array}{l}1.09 \\
1.35\end{array}$ & $\begin{array}{l}\text { Prime } \\
\text { Potential }\end{array}$ \\
\hline
\end{tabular}

The development of subsectors in Sarolangun Regency has economic development gaps, in addition to physical condition and area accessibility. Classification based on Klassen typology is dynamic because it really depends on the progress of development activities in the study area in the future. It means that in different research periods, the classification will change according to the growth rate and contribution level of subsectors to GRDP in each sector at the time of the study.

Table 4 describes that five-year development (2013-2017) resulted on the increase of prime sectors. These prime sectors were water supply, waste management, waste, and recycling, financial services and insurance, administration of government, defense, and mandatory social security, health services and social activities, and other services sector. In general, economy of Sarolangun Regency during 2013-2017 had been well developed, but in particular it was still not optimal because leading sectors were unable to compete comparatively with other sectors, such as agriculture, forestry, and fisheries sector.

Table 4 also illustrates that mining and excavating sector was no longer classified as prime sector, even though this sector was a leading sector in 2013. Progress of economic development of Sarolangun Regency in 2013-2017 became a reference for future development because there are still many leading sectors that have not received special attention, such as construction sector; large and retail trade, car and motorcycle repair sector; and educational services sector. The results of this study contradict the findings of Suandi, Syekh, Damayanti, Mukhlis \& Riswandi (2013). They conducted a study in Muaro Jambi Regency and found that there were five prime subsectors in Muaro 
Jambi Regency, namely plantation subsector, livestock and livestock products subsector, forestry subsector, fisheries subsector, and non-oil and gas industry subsector.

The results of other studies found that each regency/city has different subsector classifications depending on the resources and performance of the subsectors. Research conducted by Arianti (2011) showed that, in Bengkulu Province, livestock was prime subsector, plantation was the potential subsector, forestry was developed subsector and food crops was underdeveloped subsector. The findings were proven by the findings of Suandi, Delis \& Rainiyati (2015), that agriculture (food crops subsector and plantation subsector) was categorized in potential sector.

The fundamental problem faced by the residents of Jambi Province is the lack of access to basic household needs (food), sources of capital, markets and technology, as well as weak community organizations (Suandi, Napitupulu \& Damayanti, 2018). Future development programs must be carried out comprehensively and holistically which are oriented to the concept of sustainable welfare development (Howarth, 2012). These findings are supported by the research of Sari (2018) which stated that agriculture sector (food crops subsector, plantation subsector, and fisheries subsector) has advantages, and these subsectors are progressive subsectors and have competitiveness. Study by Sapriadi \& Hasbiullah (2015) showed different results that services sector was the leading sector which has competitiveness, while Yolamalinda (2014) found that manufacturing subsector was the leading subsector and had competitiveness.

Table 4. Growth rate and distribution of GRDP of Jambi Province and Sarolangun Regency, 2017

\begin{tabular}{|c|c|c|c|c|c|}
\hline \multirow[b]{2}{*}{ Business Fields } & \multicolumn{2}{|c|}{ Growth rate } & \multicolumn{2}{|c|}{ Contribution } & \multirow{2}{*}{$\begin{array}{c}\text { Comparative } \\
\text { Advantage }\end{array}$} \\
\hline & $\begin{array}{c}\text { Jambi } \\
\text { Province }\end{array}$ & $\begin{array}{l}\text { Sarolangun } \\
\text { Regency }\end{array}$ & $\begin{array}{c}\text { Jambi } \\
\text { Province }\end{array}$ & $\begin{array}{c}\text { Sarolangun } \\
\text { Regency }\end{array}$ & \\
\hline A. Agriculture, forestry, and fisheries & 5.43 & 4.20 & 26.97 & 28.95 & Potential \\
\hline B. Mining and excavating & 3.77 & 5.12 & 23.57 & 21.20 & Developed \\
\hline C. Manufacturing & 3.02 & 3.52 & 10.76 & 4.01 & Developed \\
\hline D. Procurement of electricity and gas & 1.70 & 6.51 & 0.05 & 0.03 & Developed \\
\hline $\begin{array}{l}\text { E. Water Supply, waste management, } \\
\text { waste, and recycling }\end{array}$ & 2.60 & 3.34 & 0.13 & 0.13 & Prime \\
\hline F. Construction & 7.22 & 5.00 & 7.19 & 14.34 & Potential \\
\hline $\begin{array}{l}\text { G. Large and retail trade; car and } \\
\text { motorcycle repair }\end{array}$ & 4.33 & 4.63 & 9.61 & 8.17 & Developed \\
\hline H. Transportation and warehousing & 5.91 & 5.55 & 3.28 & 2.01 & Underdeveloped \\
\hline $\begin{array}{l}\text { I. Provision of accommodation and } \\
\text { foods and beverages }\end{array}$ & 7.95 & 7.82 & 1.11 & 2.14 & Potential \\
\hline J. Information and communication & 6.60 & 5.30 & 3.61 & 3.69 & Potential \\
\hline K. Financial services and insurance & 3.06 & 4.05 & 2.35 & 2.69 & Prime \\
\hline L. Real estate & 4.61 & 3.93 & 1.44 & 1.32 & Underdeveloped \\
\hline M.N. Company services & 4.32 & 5.45 & 1.05 & 0.27 & Developed \\
\hline $\begin{array}{l}\text { O. Administration of government, } \\
\text { defense and mandatory social } \\
\text { security }\end{array}$ & 2.52 & 3.05 & 3.42 & 5.64 & Prime \\
\hline P. Educational services & 4.24 & 3.93 & 3.26 & 2.71 & Underdeveloped \\
\hline $\begin{array}{l}\text { Q. Health services and social } \\
\text { activities } \\
\text { R.S.T.U. Other services }\end{array}$ & $\begin{array}{l}5.49 \\
4.54\end{array}$ & $\begin{array}{l}6.60 \\
5.70\end{array}$ & $\begin{array}{l}1.15 \\
1.03\end{array}$ & $\begin{array}{l}1.30 \\
1.40\end{array}$ & $\begin{array}{l}\text { Prime } \\
\text { Prime }\end{array}$ \\
\hline
\end{tabular}

Source: BPS Jambi Province and Sarolangun Regency (2018)(processed)

Growth centers of each region have different coverage levels depending on the size and distance between the two sites, namely between the growth center and the surrounding area. According to Refika (2012), through the analysis of the gravity method 
using population data of each kecamatan and the distance between kecamatan, growth centers of kecamatan has different hinterland. Type of interactions between growth centers of kecamatan and its hinterland also varies, both in economic activities, education, and other activities. The development in one sector will encourage the development of other sectors, so that it will grow the economy as a whole. Sectors can be synergized by making sectors interrelated and mutually supportive and beneficial. For example, a plantation business can synergize with plantation business. Grass/plantation waste can be used as animal feed, otherwise animal manure can be used as fertilizer for plantation crops (Tarigan, 2012).

Sectors that were not in the leading sectors in 2017 were due to the slow growth rate of those sectors compared to the growth rate of sectors at Jambi Province level, even though the contribution rate was much higher than its rate at Jambi Province level (Table 4). Through the analysis using Klassen typology in Kubu Raya Regency period 20082013, Hajeri, Yurisinthae \& Dolorosa (2015) found that Manufacturing sector, electricity, gas, and clean water sector, and transportation and communication sector were prime subsectors. Meanwhile, agriculture sector, mining and excavating sector, construction sector, financial sector, rental and company services sector, and other services sector were potential subsectors. Agriculture sector and construction sector were sectors that had high growth rate, but had a low contribution. Trade, hotel, and restaurant was underdeveloped sector.

\section{Program and policy based on leading sectors}

To improve the economy of Sarolangun Regency in realizing the welfare of farmers and the community in a sustainable manner, a strategic development policy is needed in dealing with each sector. In other words, underdeveloped, developed, and potential sectors are the top priorities in the development program, while leading sectors need to maintain their level of contribution and growth.

From the perspective of budget policy in Sarolangun Regency, there are at least four aspects as restrictions, namely institutions, coordination, coaching, and development acceleration.

From the aspect of institution, law on national education suggests that local government, including Sarolangun Regency, should allocate 20 percent of its APBD (Anggaran Pendapatan dan Belanja Daerah/Local government budget) for activities in the education sector even though educational services sector is actually a non-basis sector categorized in underdeveloped group. In other words, educational services sector in Sarolangun Regency does not contribute to the GRDP due to its slow growth rate. According to law, this sector plays an important role for the development of Sarolangun Regency, especially in improving the quality of human resources, which can indirectly enhance development progress in various sectors. Health services and social activities sector is different from other sectors because it is a basis sector and categorized in prime group so this sector is able to fulfill the mandate of Health Act of 10 percent of APBD. Health services and social activities sector has forward and backward linkages because it generates production and GRDP revenue of Sarolangun Regency. This sector has a relatively good growth rate.

The national and provincial development programs must always coordinate so that development of Sarolangun Regency with the help of Dana Desa program by Central Government and Government of Jambi Province can be done optimally. With that 
program, Sarolangun Regency government made a program known as Serjusade (Seratus Juta per Desa) Program requiring Rp. 31 billion from APBD. Synergy of the program results on the maximum budget absorption to infrastructure activities, especially roads in village, and other productive activities in agriculture sector. It also results on having this sector as basis sector. The analysis showed that the program had not been able to encourage small and medium industries subsector and small and medium enterprises subsectors to become rubber-based and palm oil-based basis sectors of Sarolangun Regency.

In carrying out future development, Sarolangun government needs to do coaching consistently in order to maintain the following sectors as basis and prime sectors, namely (1) water supply, waste management, waste, and recycling sector; (2) financial services and insurance sector; (3) administration of government, defense, and mandatory social security sector; (4) health services and social activities sector, and (5) other services sector, while continuing to provide coaching that can drive the growth rate of (1) agriculture, forestry, and fisheries sector; (2) construction sector; (3) information and communication sector; and (4) provision of accommodation and foods and beverages sector.

Development acceleration needs to be done in non-basis sectors in developed and underdeveloped group. Those sectors are (1) mining and excavating sector; (2) manufacturing sector; (3) procurement of electricity and gas sector; (4) large and retail trade; car and motorcycle repairs sector; and (5) company services sector. The transfer of authority for mining and excavating to provincial government has resulted in the degradation of the sector to be a non-basis sector, even though the natural resources potential of mining in this regency is relatively big.

In the future, there should be strong coordination between local government and provincial government in the joint management of mining and excavating sector so that the local community can get the results of the development from their own natural resources. Local government should accelerate development in (1) transportation and warehousing sector; (2) real estate sector; and (3) educational services sector because they have relatively large potential in terms of budget and regional economic potential.

\section{CONCLUSION AND RECOMMENDATION}

\section{Conclusion}

Distribution level of leading sectors in Sarolangun Regency was based on the categorizing with Klassen typology. There are prime subsector, potential subsector, developed subsector, and underdeveloped subsector.

a. The analysis showed that from year to year, there were no significant changes in primary, secondary, and tertiary subsector. The results of the analysis showed that there were six prime sectors, namely: (1) mining and excavating; (2) water supply, waste management, waste, and recycling; (3) financial services and insurance; (4) administration of government, defense, and mandatory social security; (5) health services and social activities; and (6) other services. During the period 2013-2017, there was an increase in the number of prime sectors.

b. The distribution of potential and developed sectors in Sarolangun Regency during the 2013-2017 periods did not show significant changes, there were around 8-9 sectors. However, there were changes in the type of sectors in this group. There were some 
sectors which, even though they had large contribution and were strategic, they were in potential and developed group. Those sectors were (a) agriculture, forestry, and fisheries sector; (b) mining and excavating sector that was once a prime sector in 2013; and (c) Information and Communication sector.

c. The distribution of underdeveloped sectors in Sarolangun Regency during the 20132017 periods was still relatively high, between 3-6 sectors, although in 2017 there were only three sectors in this group. Those three sectors in 2017 were: (1) transportation and warehousing; (2) real estate; and (3) educational services. Specifically for education services sector, although it contributes a little to none to the economy of Sarolangun Regency, this sector has a special role to the long-term and sustainable development progress in Sarolangun Regency. This is because education services sector plays a role in improving the quality of human resources.

\section{Recommendation}

The Government of Sarolangun Regency must be able to maintain leading sectors or basis sectors in Sarolangun Regency in the coming years. To increasing regional revenue, the government needs to pay attention to the potential sectors, such as mining and excavation sector that has a large contribution to the regional economy but not categorized in leading sector. Innovation and technology are needed to accelerate development in those sectors. The role of government is also needed in intensify the development in Education Services sector because it is one of resource development institutions. The increasing role of educational institutions will indirectly improve the quality of regional resources.

Development programs need more in-depth research through investment analysis using ICOR (Incremental Capital Output Ratio) approach to improve productivity and efficiency. Analysis of sectorial investment needs can help local government in understanding and knowing how much investment is needed to achieve a certain level of economic growth both in sectorial and regional aggregate development. Furthermore, the availability of investment data and calculation of investment needs is very necessary in designing and formulating regional macroeconomic policies systematically, in realizing the desired level of economic growth.

\section{REFERENCES}

Arifin, Z. (2008). Penetapan Kawasan Andalan dan Leading Sektor sebagai Pusat Pertumbuhan pada Empat Koridor di Provinsi Jawa Timur. Research report (unpublished). Malang: Universitas Muhammadiyah Malang.

Arianti, N.N. (2011). Klasifikasi Subsektor Pertanian Kabupaten/Kota di Provinsi Bengkulu (Pendekatan Tipologi Klassen). Proceeding of SEMIRATA BKS-PTN, Palembang: May 2011

Arsyad, L. (2010). Ekonomi Pembangunan. Yogyakarta: Bagian Penerbit dan Percetakan STIM YKPN.

BPS. (2018). Produk Domestik Regional Bruto Kabupaten Sarolangun. Sarolangun: Badan Pusat Statistik Kabupaten Sarolangun.

BPS. (2018). Kabupaten Sarolangin dalam Angka. Sarolangun: Badan Pusat Statistik Kabupaten Sarolangun.

BPS. (2018). Produk Domestik Regional Bruto Provinsi Jambi. Jambi: Badan Pusat Statistik Provinsi Jambi. 
Hajeri, Yurisinthae, E. \& Dolorosa, E. (2015). Analisis Penentuan Sektor Unggulan Perekonomian di Kabupaten Kubu Raya. Jurnal Ekonomi Bisnis dan Kewirausahaan, 4(2): 253-269.

Howarth, R.B. (2012). Sustainability, Well- Being, and Economic Growth. Minding Nature, 5(2), 32-39.

Pratama, A.R., Sukiyono, K. \& Arianti, N.N. 2017. Analisis Subsektor Pertanian Unggulan Kabupaten/Kota Di Provinsi Bengkulu. AGRIC, 29(2), 121-136.

Qomariyah, S., Mustapit, Supriono, A. (2018). Analisis Potensi Wilayah Berbasis Komoditas Pertanian Tanaman Pangan serta Kontribusinya terhadap Perekonomian Kabupaten Bondowoso. JSEP, 11(1), 66-72.

Refika, A. (2012). Analisis Pengembangan Pusat Pertumbuhan Ekonomi di Kabupaten Banjarnegara. Economics Development Analysis Journal, 1(2), 1 - 9

Republik Indonesia. (2014). Undang-undang Republik Indonesia Nomor 23 tahun 2014 tentang Pemerintah Daerah. Jakarta: Kementerian Hukum dan Hak Asasi Manusia Republik Indonesia.

Sapriadi \& Hasbiullah. (2015). Analisis Penentuan Sektor Unggulan Perekonomian Kabupaten Bulukumba. Iqtisaduna, 1(1), 71-86

Srikandi, P., Palar, S. \& Wauran, P. (2015). Analisis Potensi Unggulan Dan Daya Saing Sub Sektor Pertanian Di Kabupaten Minahasa. Jurnal Berkala Ilmiah Efisiensi, 15(4), 100-112.

Sari, S.R. (2018). Kontribusi Sektor Pertanian Dalam Struktur Ekonomi Di Kabupaten Kaur Provinsi Bengkulu. Jurnal Agrisep, 17(2), 175-186.

Suandi, Syekh, S., Damayanti, Mukhlis \& Riswandi. (2013). Kajian Pengembangan Pusat Pertumbuhan Ekonomi di Provinsi Jambi. Research Report (unpublished), Badan Penelitian dan Pengembangan Daerah (Balitbangda) Provinsi Jambi

Suandi, Yuslidar, Suma, S. \& Damayanti, S. (2014). Hubungan Karakteristik Kependudukan dengan Kesejahteraan Keluarga di Provinsi Jambi. Piramida, $\mathrm{X}(10), 71-77$

Suandi, Arman Delis, dan Rainiyati, 2015. Penyusunan Perhitungan Kebutuhan Investasi dengan Pendekatan ICOR di Kabupaten Merangin. Laporan Penelitian (tidak dipublikasikan). Badan Perencanaan Pembangunan Daerah (Bappeda) Kabupaten Merangin.

Suandi \& Napitupulu, D.M.T. (2016). Peranan Plantation Kopi dalam Perekonomian Kabupaten Kerinci. Research Report (unpublished). Program Pascasarjana Universitas Jambi.

Suandi, Napitupulu, D.M.T \& Damayanti, Y. (2018). An Analysis of Regional Sustainable Food Security in Jambi Province. International Journal of Scientific Engineering and Research (IJSER), 6(9), 2347-3878

Sugiyanto \& Sukesi. (2010). Penelitian Pengembangan Pusat-Pusat Pertumbuhan Ekonomi di Kabupaten Lamandau. Jurnal Mitra Ekonomi dan Manajemen Bisnis, 1(2), 202-215.

Sukirno, S. (2011). Ekonomi Pembangunan: Proses Masalah, dan Dasar Kebijakan. Jakarta: Kencana Prenada Media Group.

Tarigan, R. (2012). Ekonomi Regional: Teori dan Aplikasi. Jakarta: Bumi Aksara.

Tirani, Pranoto, Y.S. \& Moelyo, H. (2018). Kontribusi Sektor Pertanian berdasarkan Keunggulan Wilayah di Kabupaten Bangka. Journal of Sustainable Agriculture, 33(1), 42-49. 
Wibowo, H., Darsono \& Nurjayanti, E.D. (2016). Identifikasi Posisi Dan Kontribusi Sektor Pertanian Dalam Perekonomian Daerah Di Kabupaten Temanggung. MEDIAGRO, 12(1), 17-26.

Yolamalinda. (2014). Analisis Potensi Ekonomi Daerah Dalam Pengembangan Komoditi Unggulan Kabupaten Agam. ECONOMICA: Journal of Economic and Economic Education, 3(1), 27 - 41. 